\title{
Vital Signs Baseline Flag
}

National Cancer Institute

\section{Source}

National Cancer Institute. Vital Signs Baseline Flag. NCI Thesaurus. Code C83451.

An indication or description that reported vital signs data is a baseline value. 